Academy Of Education Journal. Pendidikan Pancasila dan Kewarganegaraan Vol. 5 No. 2 Juli 2014

\title{
SMALL GROUP DISCUSSION BERBASIS READING GUIDE UNTUK PENINGKATAN KEAKTIFAN DAN HASIL BELAJAR PKn SISWA MTs
}

\author{
Oleh: \\ Ahmad Nasir Ari Bowo \\ Universitas Cokroaminto Yogyakarta
}

\begin{abstract}
Abstrak
Penelitian ini bertujuan untuk peningkatkan keaktifan dan hasil belajar siswa dalam proses pembelajaran PKn materi sikap positif terhadap kedaulatan rakyat dalam sistem pemerintahan Indonesia pada siswa kelas VIII MTs Darrul Quran Karangmojo Tasikamdu Karanganyar tahun 2013 melalui penerapan strategi pembelajaran small group discussion berbasis reading guide. Keaktifan siswa sangat kurang sebelum diberikan tindakan penelitian dan guru sudah mengupayakan alternatif pemecahannya, antara lain: menggunakan strategi pembelajaran diskusi, tanya jawab, dan ceramah. Hasil penerapan strategi pembelajaran tersebut belum mampu meningkatkan keaktifan dan hasil belajar siswa. Solusi yang ditawarkan dalam penelitian ini adalah dengan menggunakan strategi pembelajaran small group discussion berbasis reading guide. Subjek pelaksanaan tindakan adalah siswa kelas VIII MTs Darrul Quran Karangmojo Tasikmadu Karanganyar yang berjumlah 22 siswa. Data penelitian ini dikumpulkan melalui informan atau narasumber, tempat dan peristiwa berlangsungnya aktifitas pembelajaran. Teknik pengumpulan data dengan menggunakan metode observasi dan wawancara. Prosedur dalam penelitian ini terdapat empat tahap yaitu perencanaan, pelaksanaan, pengamatan dan refleksi. Penelitian ini dilakukan melalui satu tahap. Diharapkan dengan penerapan strategi pembelajaran small group discussion berbasis reading guide keaktifan dan hasil belajar siswa dalam proses pembelajaran PKn materi sikap positif terhadap kedaulatan rakyat dalam sistem pemerintahan Indonesia pada siswa kelas VIII MTs Darrul Quran Karangmojo Tasikmadu Karanganyar Tahun 2013 dapat meningkat minimal 80\% dari 22 siswa.

Hasil penelitian ini menunjukkan bahwa tingkat keaktifan dan hasil belajar siswa pada materi sikap positif kedaulatan rakyat dalam sistem pemerintahan Indonesia kelas VIII MTs Darrul Quran Karangmojo Tasikmadu Karanganyar Tahun 2013 yaitu dari yang aktif dalam proses pembelajaran PKn sebelum diadakan penelitian adalah 5 siswa (22,7\%), kemudian hasil belajar siswa yang memenuhi KKM (70) adalah 8 siswa (36,3\%). Setelah dilakukan tindakan yang telah disepakati yaitu dengan menerapkan strategi pembelajaran small group discussion berbasis reading guide, keaktifan siswa dalam mengikuti pembelajaran meningkat menjadi 19 siswa (86,3\%). Sedangkan hasil belajar siswa yang memenuhi KKM meningkat menjadi 20 siswa $(90,9 \%)$. Berdasarkan data hasil penelitian tersebut maka hipotesis tindakan yang menyatakan "Diduga dengan menerapkan Strategi Pembelajaran Small group Discussion berbasis Reading Guide mampu Meningkatkan Keaktifan dan Hasil Belajar Siswa dalam Proses Pembelajaran PKn Materi Sikap Positif terhadap Kedaulatan Rakyat dalam Sistem Pemerintahan Indonesia pada Kelas VIII MTs Darrul Quran Karangmojo Tasikmadu Karanganyar Tahun 2013" terbukti dan dapat diterima kebenarannya.
\end{abstract}

Kata Kunci: Small Group Discussion, Reading Guide, Keaktifan, Hasil Belajar, Sikap Positif 


\section{Pendahuluan}

Pendidikan memegang peranan yang sangat penting untuk menjamin kelangsungan hidup bermasyarakat, bangsa, dan negara. Salah satu upaya untuk meningkatkan mutu pendidikan adalah dengan cara memperbaiki proses belajar mengajar yang selama ini dipandang kurang aktif, inovatif, efektif, kreatif dan menyenangkan (PAIKEM) dan cenderung monoton.

Guna mencapai tujuan pembelajaran yang diharapkan, maka perencanaan kegiatan pembelajaran seharusnya tidak tergantung semata-mata hanya pada guru, tetapi harus mengoptimalkan potensi yang dimiliki siswa. Salah satu cara untuk mengoptimalkan potensi yang dimiliki siswa dalam kegiatan pembelajaran adalah dengan melibatkan siswa berperan aktif dalam proses pembelajaran. Namun, pada kenyataanya proses pembelajaran belum sesuai dengan apa yang diharapkan. Hal tersebut dikarenakan pada umumnya masih bersifat konvensional, dengan menempatkan guru sebagai satu-satunya sumber belajar. Guru lebih sering menggunakan strategi ceramah tanpa diselingi dengan strategi pembelajaran aktif, sehingga menyebabkan siswa menjadi pasif dengan hanya menerima materi penjelasan dari guru tanpa ikut berperan aktif dalam proses pembelajaran, dan menimbulkan rendahnya keaktifan siswa serta tingkat perhatian siswa terhadap materi pelajaran menjadi menurun. Hasil belajarnya pun juga masih rendah.

Berikut ini contoh penelitian yang dilakukan oleh salah satu mahasiswa mengenai pembelajaran konvensional dengan hanya menggunakan strategi ceramah. Salah satunya hasil penelitian yang dilakukan oleh Miatun (2011:1-2) di SMK Muhammadiyah Delanggu Klaten pada siswa kelas XI TKR 2, mengemukakan bahwa pada saat proses pembelajaran PKn berlangsung, metode pembelajaran yang dilaksanakan oleh guru hanya ceramah dan penugasan, sehingga metode pembelajaran tersebut kurang efektif dalam meningkatkan keaktifan siswa.

Berkaitan dengan hal tersebut maka berdasarkan hasil observasi dan wawancara yang dilakukan peneliti kepada Ali Imron S.Pd selaku guru siswa kelas VIII MTs Darrul Qur'an Karangmojo Tasikmadu Karanganyar, diperoleh hasil bahwa pada saat proses pembelajaran berlangsung ditemukan beberapa masalah, salah satunya adalah guru masih menggunakan metode ceramah dalam menyampaikan materi pelajaran, sehingga berakibat pada rendahnya keaktifan siswa dalam mengikuti proses pembelajaran. Keaktifan tersebut meliputi keaktifan 
dalam memperhatikan penjelasan guru, keaktifan bertanya, berpendapat dan menjawab pertanyaan, sehingga hasil belajarnya pun juga masih rendah.

Mata pelajaran PKn merupakan mata pelajaran yang memfokuskan pada pembentukan diri yang beragam dari segi agama, sosio kultural, bahasa, usia dan karakter. Hasil pengamatan peneliti sebagai guru ketika mengajar mata pelajaran PKn dengan menggunakan metode ceramah pada kelas VIII di MTs Darrul Qur'an Karangmojo Tasikmadu Karanganyar. Dapat diketahui bahwa dari 22 siswa, hanya 5 siswa saja yang aktif dalam mengikuti proses pembelajaran. Hasil belajar siswa pun juga masih rendah. Dari keseluruhan siswa hanya 8 siswa saja yang memenuhi nilai kriteria ketuntasan minimal (KKM).

Untuk mengatasi masalah tersebut peneliti dan atau guru sudah mencoba melakukan beberapa cara diantaranya dengan menggunakan metode diskusi, penugasan, dan meminta siswa satu persatu untuk menjawab pertanyaan yang diajukan. Akan tetapi, metode dan cara yang diterapkan teryata belum berhasil meningkatkan keaktifan dan hasil belajar siswa dalam proses pembelajaran. Permasalah yang terjadi dalam pembelajaran PKn tersebut maka perlu dilakukan alternatif lain yang diharapkan mampu meningkatkan keaktifan dan hasil belajar.

Berkaitan dengan keaktifan dan hasil belajar, menurut hasil penelitian Haryati (2012) menunjukkan bahwa small group discussion dikolaburasikan dengan strategi team quis dalam pembelajaran PKn pada siswa kelas VII D SMP Negeri 2 Jatipuro Karanganyar dapat meningkatkan ketuntasan belajar materi makna proklamasi kemerdekaan dan konstitusi pertama. Selanjutnya hasil penelitian Ernawati (2012) menunjukkan bahwa, strategi pembelajaran Kolaborasi Reading Guide dengan True or False dapat meningkatkan keaktifan dalam pembelajaran PKn pada siswa kelas X Program Keahlian Pemasaran 1 SMK Negeri 1 Banyudono Tahun Ajaran 2011/2012, terbukti dan dapat diterima kebenarannya.

Small group discussion atau diskusi kelompok kecil adalah "suatu proses yang teratur yang melibatkan sekelompok individu dalam suatu interaksi tatap muka secara kooperatif untuk tujuan membagi informasi, membuat keputusan dan memecahkan masalah", (http://mashafid78.Blong-spot.com). Sedangkan Bariroh (2010) mengatakan bahwa: Metode reading guide adalah strategi yang memandu peserta didik untuk membaca panduan yang disiapkan oleh guru sesuai dengan materi yang akan diajarkan dengan waktu yang sudah ditentukan, disisi lain guru juga akan memberi pertanyaan yang akan membahas seputar materi yang telah dibaca oleh 
peserta didik setelah kegiatan membaca tersebut dengan panduan bacaan yang telah diberikan guru tersebut. Dari beberapa hasil penelitian diatas, dapat diketahui bahwa strategi small groud discussion dan reading guide dapat meningkatkan keaktifan dan ketuntasan belajar siswa.

Berdasarkan permasalah yang terjadi pada siswa kelas VIII MTs Darrul Qur'an Karangmojo Tasikmadu Karanganyar mengenai rendahnya keaktifan dan hasil belajar dalam pembelajaran PKn, peneliti menawarkan solusi untuk mengatasi masalah tersebut, yakni dengan penerapan strategi small group discussion berbasis reading guide untuk peningkatkan keaktifan dan hasil belajar siswa. Strategi ini diharapkan dapat meningkatkan keaktifan dan hasil belajar siswa dalam proses pembelajaran PKn. Siswa tidak hanya sebagai objek pembelajaran yang hanya mendengar dan menghafal apa yang disampaikan guru, tetapi dapat mengembangkan kemampuan berfikir kritis yang dimilikinya dengan melakukan berbagai aktivitas pembelajaran seperti menganalisis, membandingkan, serta mencocokkan bahan materi pelajaran. Peran siswa tidak hanya sebagai subjek pembelajaran, tetapi juga sebagai objek pembelajaran, sedangkan guru berperan sebagai fasilitator, pembimbing dan evaluator. Berdasarkan latar belakang masalah di atas maka peneliti tertarik untuk mengadakan penelitian mengenai penerapan small group discussion berbasis reading guide untuk peningkatan keaktifan dan hasil belajar PKn pada siswa kelas VIII MTs Darrul Qur'an Karangmojo kecamatan Tasikmadu kabupaten Karanganyar Tahun 2013.

Perumusan penelitian sebagai berikut: "apakah penerapan strategi small group discussion berbasis reading guide dapat meningkatkan keaktifan dan hasil belajar PKn pada siswa kelas VIII MTs Darrul Qur'an Karangmojo Kecamatan Tasikmadu Kabupaten Karanganyar tahun 2013?". Tujuan penelitian ini meliputi tujuan umum dan tujuan khusus, masing-masing tujuan tersebut dipaparkan sebagai berikut:

1. Tujuan umum

a. Untuk meningkatkan keaktifan siswa dalam bertanya dan mengemukakan pendapat serta menjawab pertanyaan.

b. Untuk meningkatkan hasil belajar siswa minimal pencapaian KKM (kriteria ketuntasan minimal). 


\section{Tujuan khusus}

Untuk meningkatkan keaktifan dan hasil belajar siswa melalui penerapan strategi small group discussion berbasis reading guide dalam pembelajaran PKn pada siswa kelas VIII MTs Darrul Qur'an Karangmojo Kecamatan Tasikmadu Kabupaten Karanganyar tahun 2013.

\section{Metode Penelitian}

Tempat penelitian ini adalah MTs Darrul Quran Karangmojo Tasikmadu Karanganyar Tahun 2013. Tahap-tahap pelaksanaan kegiatan sejak persiapan sampai dengan penulisan laporan penelitian secara keseluruhan dilakukan selama kurang lebih empat bulan, yaitu sejak bulan April sampai dengan bulan Juli 2013. Subjek dalam penelitian ini adalah peneliti, sebagai guru PKn kelas VIII MTs Darrul Quran Karangmojo Tasikamdu Karanganyar bertindak sebagai subjek pelaksana, merencanakan, mengumpulkan data, menganalisis data, dan membuat kesimpulan penelitian. Kepala sekolah dan guru MTs Darrul Quran Karangmojo Tasikamdu Karanganyar tahun 2013 sebagai subjek yang membantu dalam memberikan izin dalam penelitian ini. Seluruh siswa kelas VIII MTs Darrul Quran Karangmojo Tasikamdu Karanganyar sebagai subjek penelitian yang menerima. Data penelitian ini dikumpulkan dari berbagai sumber yang meliputi:

1. Informan atau narasumber, yaitu guru dan siswa kelas VIII MTs Darrul Quran Karangmojo Tasikmadu Karanganyar.

2. Tempat dan peristiwa berlangsungnya aktivitas pembelajaran. Lokasinya adalah MTs Darrul Quran Karangmojo Tasikmadu Karanganyar.

Teknik pengumpulan data yang digunakan dalam penelitian ini adalah dengan teknik observasi dan wawancara.

\section{Metode Observasi}

Metode observasi digunakan untuk mengamati keaktifan dan hasil belajar siswa kelas VIII MTs Darrul Qur'an Karangmojo Tasikmadu Karanganyar pada saat proses pembelajaran dengan menggunakan strategi pembelajaran small group discussion berbasis reading guide pada mata pelajaran PKn.

\section{Metode Wawancara}

Metode wawancara digunakan untuk memperkuat dan memperjelas data yang diperoleh melalui metode observasi, yaitu data mengenai keaktifan dan hasil belajar kelas VIII MTs Darrul Quran 
Karangmojo Tasikmadu Karanganyar Tahun 2013. Penelitian ini menggunakan dua macam triangulasi, yang pertama triangulasi sumber data yang berupa informasi dari guru dan siswa tentang tindakan yang diterapkan. Kedua triagulasi teknik atau metode pengumpulan dari hasil observasi dan wawancara. Teknik analisis data dalam penelitian ini menggunakan teknik analisis data model alir. Adapun langkah-langkah teknik analisis data model alir menurut Miles dan Huberman (1992:15-19) adalah sebagai berikut:

1. Pengumpulan data

2. Reduksi data

3. Penyajian data

4. Penarikan kesimpulan,

Diharapkan dengan penerapan strategi pembelajaran small group discussion berbasis reading guide keaktifan dan hasil belajar siswa dalam pembelajaran PKn kelas VIII MTs Darrul Quran Tahun 2013 dapat meningkat minimal 80\% dari 22 siswa. Menurut Arikunto (2006:16-20) model penelitian secara garis besar terdapat empat tahapan yang harus dilalui, yaitu (1) perencanaan (2) pelaksanaan, (3) pengamatan, (4) refleksi.

1. perencanaan, meliputi Identifikasi masalah, perencanaan solusi masalah.

2. Pelaksanaan Tindakan

3. Observasi

4. Refleksi

\section{Hasil Penelitian dan Pembahasan}

\section{Profil MTs Darrul Quran Karangmojo Tasikmadu Karanganyar}

Sekolah yang menjadi tempat penelitian adalah MTs Darrul Quran Karangmojo Tasikmadu Karanganyar. Sekolah ini beralamat di Karangmojo Rt 04/I Tasikmadu Karanganyar Jawa tengah. Ditinjau dari kuantitas gurunya, MTs Darrul Quran Karangmojo Tasikmadu Karanganyar lulusan sarjana pendidikan dan pondok pesantren. Sekolah ini baru terdapat dua kelas yaitu kelas VII dan kelas VIII. Jumlah siswa di MTs Darrul Quran Karangmojo Tasikmadu Karanganyar adalah 46. Siswa kelas VIII yang digunakan sebagai sampel berjumlah 22.

2. Kondisi Awal Kelas VIII MTs Darrul Quran Karangmojo Tasikmadu Karanganyar 
Berdasarkan pengalaman peneliti sebagai guru, ketika mengajar mata pelajaran PKn sebelumnya, jumlah siswa kelas VIII yang aktif berjumlah 5 siswa (22,7\%). Sedangkan hasil belajar yang memenuhi kriteria KKM (minimal 70) baru 8 siswa (36\%) dari keseluruhan siswa. Secara lebih rinci daftar keaktifan dan hasil belajar siswa kelas VIII MTs Darrul Quran Karangmojo Tasikmadu Karanganyar dapat dilihat pada tabel di bawah ini.

Tabel 1. Daftar keaktifan dan hasil belajar siswa kelas VIII sebelum pelaksanaan tindakan

\begin{tabular}{|c|l|l|}
\hline No & \multicolumn{1}{|c|}{ Keaktifan Siswa } & \multicolumn{1}{|c|}{ Banyak (prosentase) } \\
\hline 1 & Keaktifan bertanya & 2 siswa $(9,09 \%)$ \\
\hline 2 & Keaktifan dalam mengemukakan pendapat atau ide. & 1 siswa (4,54\%) \\
\hline 3 & Keaktifan menjawab pertanyaan & 2 siswa $(9,09 \%)$ \\
\hline \multicolumn{2}{|c|}{ Jumlah Total } & 5 siswa $(22,7 \%)$ \\
\hline \multicolumn{2}{|c|}{ Hasil Belajar Siswa } & \multicolumn{1}{|c|}{ Banyak (prosentase) } \\
\hline 1 & Benar menjawab pertanyaan secara lesan (KKM) & 3 siswa (13,63\%) \\
\hline 2 & Benar menjawab soal tertulis (KKM) & 5 siwa (22,72\%) \\
\hline \multicolumn{2}{|c|}{ Jumlah Total } & 8 siswa (36\%) \\
\hline
\end{tabular}

Sumber: Hasil pengamatan selama mengajar kelas VIII MTs Darrul Qur’an Karangmojo Tasikmadu Karanganyar

Dari hasil tersebut, perlu diadakan langkah alternatif yang diharapkan mampu meningkatkan keaktifan dan hasil belajar siswa pada mata pelajaran PKn materi sikap positif terhadap kedaulatan rakyat dalam sistem pemerintahan Indonesia. Untuk itu peneliti menerapkan strategi pembelajaran small group discussion berbasis reading guide. Alasan dipilihnya strategi tersebut karena strategi ini memiliki beberapa kelebihan dibandingkan dengan strategi lainnya. Kelebihan strategi pembelajaran ini antara lain siswa akan lebih aktif dalam mengikuti pelajaran karena setiap siswa akan terlibat dalam proses pembelajaran ini, meliputi kerja sama tim, memecahkan berbagai permasalahan yang ada terkait soal dan pembagian tugas yang berbedabeda. Dengan demikian keaktifan dan hasil belajar siswa dalam mengikuti pelajaran dapat meningkat. 


\section{Dialog Awal dan Pengamatan dengan Beberapa Guru dan Siswa Kelas VIII MTs Darrul Quran Karangmojo Tasikmadu Karanganyar}

Penelitian mulai dilaksanakan pada bulan April 2013, diawali dengan dialog awal antara peneliti, beberapa guru dan siswa ${ }^{1}$. Selain itu, juga pengamatan peneliti sebagai guru PKn dalam mengajar. Selanjutnya diperoleh permasalahan yang ada pada kelas tersebut. Kemudian dapat disimpulkan permasalahan yang ada pada kelas VIII adalah rendahnya keaktifan bertanya dan berpendapat serta menjawab pertanyaan di saat proses pembelajaran berlangsung. Hal tersebut juga berakibat rendahnya hasil belajar siswa.

Setelah kegiatan merumuskan masalah di atas, dilanjutkan dengan mengidentifikasi faktorfaktor penyebab masalah. Adapun asumsi penyebab masalah sebagaimana tercantum dalam tabel di bawah ini.

Tabel 2. Asumsi Penyebab Masalah

\begin{tabular}{|c|l|l|}
\hline No & \multicolumn{1}{|c|}{ Faktor } & \multicolumn{1}{c|}{ Penyebab Masalah } \\
\hline 1 & & $\begin{array}{l}\text { a. Pasif dalam menerima materi pelajaran. } \\
\text { b. Sulit untuk mengutarakan ide/gagasan, kurang kreatif. } \\
\text { c. Siswa tidak paham tentang pelajaran PKn } \\
\text { d. Tidak berani bertanya jika mendapat kesulitan. } \\
\text { e. Meremehkan mata pelajaran PKn. }\end{array}$ \\
\hline 2 & Guru & $\begin{array}{l}\text { a. Kurang membantu siswa untuk mencapai tujuan pembelajaran. } \\
\text { b. Kurang memberi motivasi. } \\
\text { c. Kurang mendorong siswa untuk mengeluarkan pendapatnya. }\end{array}$ \\
\hline 3 & $\begin{array}{l}\text { Proses } \\
\text { Pembelajaran }\end{array}$ & $\begin{array}{l}\text { a. Kurang menarik perhatian siswa. } \\
\text { b. Penyampaian materi ajar kurang variatif. } \\
\text { c. Cenderung satu arah }\end{array}$ \\
\hline 4 & Materi ajar & Kompleks \\
\hline
\end{tabular}

Berdasarkan tabel 2 di atas dapat diketahui bahwa penyebab masalah yang paling dominan adalah pasif dalam menerima informasi dan sulit mengutarakan ide atau pendapat, sehingga berpusat pada guru dalam proses pembelajaran. Maka dari itu peniliti sebagai guru PKn merumuskan solusi dan rencana kegiatan yang perlu di lakukan.

\footnotetext{
${ }^{1}$ Dialog awal dilaksanakan pada hari Minggu, 21 April 2013 pukul 09.30 WIB di ruang guru dan kelas untuk mengetahui berbagai permasalahan guru ketika mengajar kelas VIII.
} 
Tindakan solusi masalah yang ditawarkan dalam penelitian ini adalah dengan penerapan strategi small group discussion berbasis reading guide untuk peningkatan keaktifan dan hasil belajar siswa MTs. Karena peneliti sebagai guru PKn, maka peneliti mengimplementasikan penelitian ini pada mata pelajaran PKn materi sikap positif terhadap kedaulatan rakyat dalam sistem pemerintahan Indonesia MTs Darrul Quran Karangmojo Tasikmadu Karanganyar tahun 2013 kelas VIII.

Penggunaan strategi small group discussion berbasis reading guide diharapkan dapat mengubah pembelajaran yang semula siswa hanya pasif menjadi lebih aktif dalam bertanya maupun berpendapat serta menjawab pertanyaan dengan baik sehingga hasil belajarnya pun juga meningkat. Selanjutnya pembelajaran yang semula hanya berpusat pada guru akan berubah menjadi pembelajaran yang berpusat pada siswa dan guru hanya sebagai fasilitator.

\section{Perencanaan Tindakan Penelitian}

Berdasarkan hasil serangkaian kegiatan pada dialog awal, terlihat bahwa pembelajaran PKn belum dapat dilaksanakan dengan baik sehingga hasil belajar yang dicapai peserta didik belum optimal. Sebelum tindakan pembelajaran, peneliti merancang perencanaan pembelajaran guru (RPP) dan pembagian segmen materi yang akan disampaikan pada siswa. Selain itu peneliti juga mempelajari buku-buku terkait strategi pembelajaran. Adapun strategi yang peneliti terapkan adalah small group discussion berbasis reading guide. Kajian mengenai strategi pembelajaran small group discussion dan reading guide meliputi

1. Langkah-langkah strategi small group discussion.

a. Bagilah kelas ke dalam kelompok kecil.

b. Berikan bacaan untuk masing-masing kelompok.

c. Minta mereka untuk mendiskusikan bacaan.

d. Mintalah setiap kelompok untuk menujuk juru bicara.

e. Minta para juru bicara kelompok untuk mempresentasikan hasil diskusi kelompoknya.

f. Mintalah kelompok lain untuk bertanya atau menanggapi.

g. Guru memberikan rangkuman atau pengatan-penguatan materi. (http://mashafid78.Blongspot.com).

2. Langkah-langkah pelaksanaan strategi reading guide antara lain:

1) Tentukan bacaan yang dipelajari. 
2) Buat pertanyaan-pertanyaan yang akan dijawab oleh peserta didik atau kisi-kisi dan boleh juga bagan atau skema yang dapat diisi oleh mereka dari bahan bacaan yang telah dipilih tadi.

3) Bagikan bahan bacaan dengan pertanyaan atau kisi-kisinya kepada peserta didik.

4) Tugas peserta didik adalah mempelajari bahan bacaan dengan menggunakan pertanyaan atau kisi-kisi yang ada. Batasi aktifitas ini sehingga tidak akan memakan waktu yang berlebihan.

5) Bahas pertanyaan atau kisi-kisi tersebut dengan menanyakan jawabannya kepada peserta didik.

6) Di akhir pelajaran beri ulasan secukupnya (Zaini dkk. 2008:8-9).

Peneliti menggabungkan kedua strategi tersebut yaitu strategi small group discussion berbasis reading guide. Adapun langkah-langkah penerapan strategi tersebut antara lain:

1) Siswa di bagi menjadi beberapa kelompok kecil.

2) Setiap kelompok di beri sub tema, ringkasan materi dan soal yang berbeda-beda.

3) Setiap kelompok mempelajari sub tema dan ringkasan materi kemudian diskusi dan menjawab beberapa latihan soal yang sudah disediakan oleh guru

4) Setiap kelompok melakukan presentasi terkait sub tema dan membahas soal yang telah dikerjakan di depan kelas, kemudian dilanjutkan tanya jawab secara bergantian.

5) Siswa menjawab pertanyaan secara lisan terkait materi.

6) Guru memberi konfirmasi dan penguatan terkait materi pembelajaran.

\section{Pelaksanaan Tindakan Penelitian}

Tindakan dilaksanakan sesuai dengan isi rancangan pembelajaran dan menerapkan rancangan tindakan yang telah disusun berdasarkan permasalahan yang diduga mempengaruhi pembelajaran PKn yang berakibat pada kurangnya keaktifan dan hasil belajar siswa dalam proses pembelajaran PKn siswa kelas VIII. Tindakan merupakan langkah awal dalam pelaksanaan penelitian. Langkah ini terdiri dari beberapa tahap antara lain sebagai berikut:

a. Pelaksanaan tindakan

Strategi pembelajaran yang digunakan adalah small group discussion berbasisi reading guide. Alokasi waktunya 2 jam pelajaran @ 40 menit dan didistribusikan ke dalam satu rencana pembelajaran. Untuk lebih jelasnya tentang rencana pelaksanaan pembelajaran (RPP) sebagaimana dipaparkan dalam tabel di bawah ini. 
Tabel 3. Lesson Plan atau RPP Tindakan Penelitian

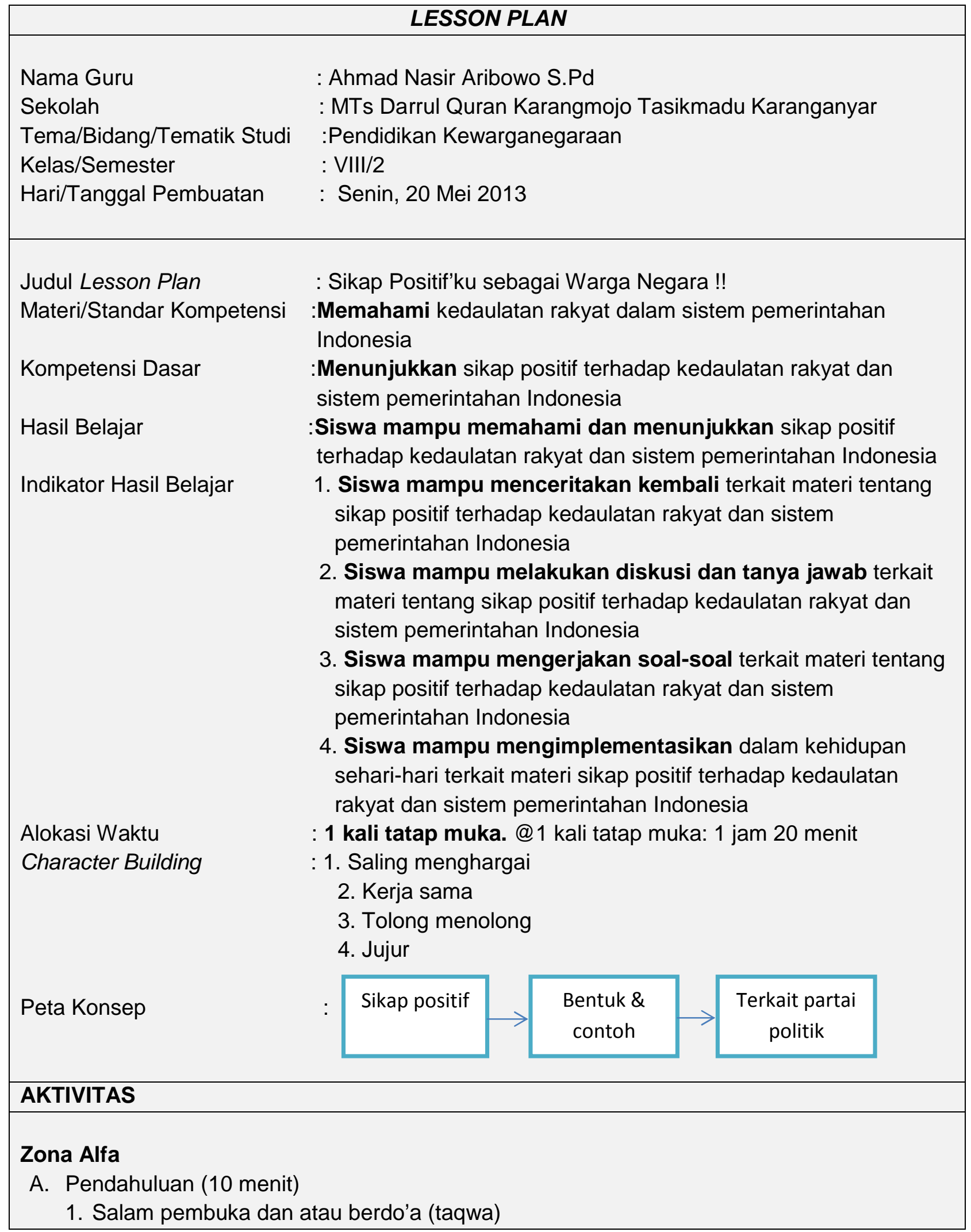


2. Ice breaking

3. Absensi dan menanyakan keadaan siswa (empati, peduli, dan disiplin)

4. Apersepsi : memotivasi siswa tentang perubahan

B. Kegiatan Inti (55 menit)

Strategi Pembelajaran: small group discussion berbasis reading guide

1. Siswa mendengarkan penjelasan guru terkait pembelajaran hari ini (eksplorasi)

2. Siswa dibagi menjadi beberapa kelompok kecil (eksplorasi)

3. Setiap kelompok diberi sub tema, ringkasan materi, dan soal yang berbeda-beda (eksplorasi)

4. Setiap kelompok mempelajari dan berdiskusi terkait sub tema dan materi, kemudian mengerjakan soal yang telah diberikan. (eksplorasi, elaburasi)

5. Setiap kelompok melakukan presentasi terkait sub tema materi dan membahas latihan soal yang telah dikerjakan, selanjutnya melakukan diskusi dan tanya jawab secara bergantian (elaburasi, konfirmasi)

6. Siswa menjawab pertanyaan secara lesan terkait materi yang telah disampaikan (Konfirmasi)

7. Guru memberi penguatan terkait materi yang telah dipelajari. (konfirmasi)

Karakter: tanggung jawab, saling menghargai pendapat, percaya diri, jujur, adil.

C. Penutup (10 menit)

1. Guru dan siswa menyimpulkan materi yang dipelajari.

2. Tindak lanjut dan informasi pertemuan berikutnya: pertemuan selanjutnya akan melakukan evaluasi terhadap materi yang telah dipelajari hari ini

3. Homework:

a. Siswa membaca materi-materi yang telah dipelajari pada modul

b. siswa mencatat atau menulis materi-materi yang belum di pahami

4. Salam penutup

Sumber Ajar

1. Buku ajar modul PKn kelas VII SMP Penulis MS Faridy. Buku-buku terkait materi yang dipelajari

2. Website berbagai sumber terkait materi yang dipelajari

3. Artikel atau majalah solopos dan kompas

4. LKS pembelajaran PKn MGMP PKn MTs Kab. Karanganyar

Alat

Kertas hvs, laptop, LCD, alat-alat tulis

Teknik dan bentuk Instrumentasi

Presentasi, keaktifan, pemahaman, tingkah laku, kemampuan menjawab soal

Contoh Soal

Uraian. 


\begin{tabular}{|c|c|c|c|c|c|}
\hline \multicolumn{6}{|c|}{ PENILAIAN } \\
\hline \multicolumn{6}{|c|}{ Rubrik Penilaian Klasifikasi } \\
\hline No & Kriteria & Bobot & $A$ & $\mathrm{~B}$ & C \\
\hline 1. & Ketepatan jumlah betul & $60 \%$ & $100 \%$ benar & $90-60 \%$ & $50 \%$ ke bawah \\
\hline 2. & $\begin{array}{l}\text { Keaktifan, kreatifitas, } \\
\text { kedisiplinan, tingkah laku }\end{array}$ & $40 \%$ & Amat baik & Baik & Kurang \\
\hline \multicolumn{6}{|c|}{ Rubrik presentasi proyek } \\
\hline No & Kriteria & Bobot & $A$ & $\mathrm{~B}$ & C \\
\hline 1 & Kualitas proyek & $40 \%$ & Baik & sedang & Kurang \\
\hline 2 & Alur penjelasan & $30 \%$ & Terarah, jelas & Biasa saja & Kurang jelas \\
\hline 3 & Intonasi suara & $20 \%$ & Jelas & Biasa saja & Kurang \\
\hline
\end{tabular}

Kepala Sekolah

Karanganyar, 20 Mei 2013

Guru/Peneliti

H. Achmad Busyairi, M.Ag

Ahmad Nasir Aribowo

NB: Ringkasan Materi terlampir

b. Hasil Tindakan

1) Hasil Observasi atau Monitoring antara lain:

a) Proses pembelajaran

Proses pembelajaran dimulai dengan pendahuluan, inti, dan penutup. Terkait proses pembelajaran, lebih jelasnya dapat di lihat pada tabel 3 tentang rencana pelaksanaan pembelajaran (RPP).

b) Keaktifan dan hasil belajar siswa kelas VIII

Keaktifan peserta didik kelas VIII sudah mulai terlihat. Secara keseluruhan jumlah siswa yang aktif baik bertanya, aktif dalam mengemukakan pendapat atau ide dan keaktifan siswa dalam menjawab pertanyaan serta hasil belajar siswa meningkat. Secara terperinci dapat dilihat tabel dibawah ini. 
Tabel 4. Daftar keaktifan dan hasil belajar siswa kelas VIII

\begin{tabular}{|l|l|l|}
\hline No & \multicolumn{1}{|c|}{ Keaktifan Siswa } & \multicolumn{1}{c|}{ Jumlah } \\
\hline 1 & Keaktifan bertanya & 6 siswa $(27,2 \%)$ \\
\hline 2 & Keaktifan mengemukakan pendapat atau ide. & 5 siswa $(22,7 \%)$ \\
\hline 3 & Keaktifan menjawab pertanyaan. & 8 siswa $(36,3 \%)$ \\
\hline \multicolumn{2}{|c|}{ Jumlah Total } & 19 siswa $(86,3 \%)$ \\
\hline \multicolumn{2}{|c|}{ Hasil Belajar Siswa } \\
\hline 2 & Benar menjawab pertanyaan lesan & 9 siswa $(40,9 \%)$ \\
\hline \multicolumn{2}{|c|}{ Jumlah Total } & 11 siswa $(50 \%)$ \\
\hline
\end{tabular}

Berdasarkan tabel di atas, dapat diketahui bahwa secara umum keaktifan siswa meningkat menjadi $86,3 \%$. Sedangkan hasil belajar siswa meningkat menjadi $(90,9 \%)$

a. Refleksi

Kegiatan refleksi ini mendiskusikan hasil observasi selama pembelajaran. Refleksi dilakukan setelah pembelajaran selesai. Hasil refleksi diperoleh beberapa kesepakatan yaitu:

1) Pembelajaran melalui strategi small group discussion berbasis reading guide jauh lebih baik dibanding pembelajaran-pembelajaran sebelumya.

2) Keaktifan siswa meningkat menjadi 19 siswa (86,3\%) dan hasil belajar siswa meningkat menjadi 20 siswa $(90,9 \%)$.

3) Pembelajaran dengan strategi small group discussion berbasis reading guide dapat diterapkan secara optimal.

Berdasarkan pembelajaran secara keseluruhan, usaha untuk mengatasi permasalahan yaitu rendahnya keaktifan dan hasil belajar siswa sudah mengalami perubahan yang positif. Maka dari itu perlu diadakan pengembangan penerapan strategi pembelajaran small group discussion berbasis readig guide, sehingga keaktifan dan hasil belajar siswa dapat lebih merata.

Hasil observasi dan refleksi diperoleh tindakan pembelajaran yang dilakukan oleh peneliti yang sesuai dengan harapan yaitu:

1) Keaktifan dan hasil belajar siswa dalam pembelajaran mengalami peningkatan yang memuaskan, siswa tidak takut lagi dalam mengemukakan pendapat maupun bertanya.

2) Minat siswa dalam mengikuti pelajaran meningkat dapat dilihat dari hasil observasi aspek afektif siswa. 
3) Hasil belajar siswa mengalami peningkatan (70\% - 100\%) yang sangat berarti, ini terlihat pada hasil nilai yang semakin meningkat.

4) Pembelajaran dengan strategi small group discussion berbasis reading guide secara benar dan optimal dapat meningkatkan keaktifan $(86,3 \%)$ dan hasil belajar $(90,9 \%)$. Selain itu strategi small group discussion berbasis reading guide juga dapat menumbuhkan rasa solidaritas dan kerjasama antar teman.

\section{Evaluasi Peningkatkan Keaktifan dan Hasil Belajar Siswa dalam Pembelajaan PKn}

Pembahasan terhadap permasalahan penelitian berdasarkan analisis data kualitatif hasil penelitian, serta profil kelas sebelum dan sesudah penelitian yang dibuat oleh peneliti untuk melakukan tindakan dimulai dari: (1) perencanaan, (2) pelaksanaan, (3) pengamatan, (4) refleksi hasilnya sebagai berikut: Dalam proses pembelajaran PKn materi sikap positif terhadap kedaulatan rakyat dalam sistem pemerintahan Indonesia melalui strategi small group discussion berbasis reading guide telah memberikan dorongan kepada peneliti atau guru untuk mengembangkan strategi pembelajaran baru yang inovatif dalam melakukan pembelajaran yang mengikut sertakan siswa, sehingga proses pembelajaran tidak berpusat pada guru.

Pembelajaran dengan strategi small group discussion berbasis reading guide meminta siswa aktif berinteraksi dengan sesama temannya. Mereka lebih aktif dalam bertanya maupun berpendapat serta menjawab pertanyaan agar lebih mudah memahami materi dan terlibat langsung dalam proses pembelajaran, sehingga hasil belajarnya pun juga mengalami peningkatan.

Dapat terlihat bagaimana peningkatan keaktifan dan hasil belajar siswa mulai dari sebelum penelitian hingga penelitian berakhir. Tingkat keaktifan yaitu sebanyak 5 siswa $(22,7 \%)$, sedangkan hasil belajar yaitu sebanyak 8 siswa (36,3\%). Setelah dilakukan tindakan yang disepakati yaitu dengan menerapkan strategi pembelajaran small group discussion berbasis reading guide pada pembelajaran diperoleh hasil untuk jumlah siswa yang aktif meningkat menjadi 19 siswa (86,3\%). Sedangkan hasil belajar siswa meningkat menjadi 20 siswa (90,9\%) dari 20 siswa keseluruhan. 
Gambar 1. Peningkatan Keaktifan dan Hasil Belajar Siswa kelas VIII

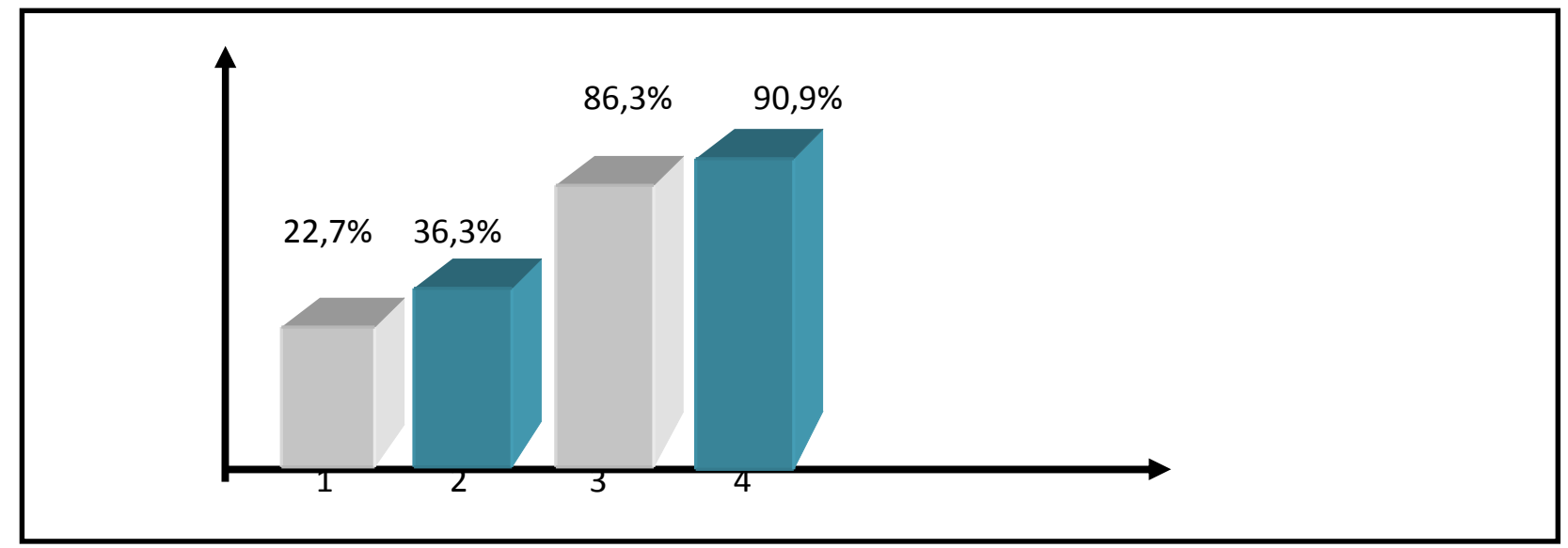

Keterangan:

1. Keaktifan siswa pada kondisi awal sebanyak $5(22,7 \%)$ siswa.

2. Hasil belajar siswa pada kondisi awal sebanyak $8(36,3 \%)$ siswa.

3. Keaktifan siswa setelah tindakan sebanyak $19(86,3 \%)$ siswa.

4. Hasil belajar siswa setelah tindakan sebanyak 20 (90,9\%) siswa.

Berdasarkan penelitian yang dilakukan, peneliti dapat mengetahui kelebihan dan kekurangan pembelajaran dengan menggunakan strategi small group discussion berbasis reading guide yaitu sebagai berikut:

\section{Kelebihan}

a. Siswa lebih mudah memahami pelajaran karena terlibat langsung dalam pembelajaran.

b. Siswa lebih tertarik mengikuti pelajaran.

c. Pembelajaran dengan strategi small group discussion berbasis reading guide membuat siswa lebih aktif dan hasil belajar meningkat.

\section{Kekurangan}

a. Dalam pembelajaran ini guru perlu membuat media yang menarik untuk memudahkan siswa dalam memahami materi pelajaran PKn, guru harus mencari variasi model pembelajaran yang dapat dikombinasikan.

b. Dibutuhkan ruangan kelas yang memadai agar pembelajaran dapat berjalan dengan lancar.

c. Dibutuhkan pengelolaan kelas yang baik demi tercapainya tujuan yang diharapkan. 


\section{Kesimpulan}

Dari rangkaian pembahasan penelitian yang telah dilakukan terlihat adanya perubahan yang merupakan hasil penelitian dalam rangka usaha meningkatkan keaktifan dan hasil belajar siswa pada materi sikap positif terhadap kedaulatan rakyat dalam sistem pemerintahan Indonesia. Bertitik tolak dari tindakan yang telah dilaksanakan pada penelitian ini, maka dapat diambil beberapa kesimpulan sebagai berikut:

1. Penerapan strategi pembelajaran small group discussion berbasis reading guide pada mata pelajaran PKn materi sikap positif terhadap kedaulatan rakyat dalam sistem pemerintahan Indonesia telah mampu meningkatkan keaktifan bertanya dan berpendapat serta menjawab pertanyaan hingga sebanyak $19(86,3 \%)$ siswa. Selain itu juga dapat meningkatkan hasil belajar. Hal tersebut terbukti ketika siswa menjawab pertanyaan lesan dan menjawab soal tertulis dengan baik, dengan nilai minimal 70 (KKM) sebanyak 20 (90,9\%) siswa. Peningkatan keaktifan dan hasil belajar diamati melalui kegiatan pembelajaran dengan strategi small group discussion berbasis reading guide.

2. Keaktifan dan hasil belajar siswa meningkat. Sebelum adanya penelitian siswa yang aktif sebanyak 5 siswa atau 22,7\%. Sedangkan hasil belajar yang memenuhi KKM sebanyak 8 siswa atau 36,3\%. Setelah dilakukan tindakan penelitian keaktifan siswa meningkat menjadi 19 siswa atau 86,3\%. Sedangkan hasil belajar yang memenuhi KKM meningkat menjadi 20 siswa atau $90,9 \%$. 


\section{Daftar Pustaka}

Arikunto, Suharsimi. 2006. Prosedur Penelitian Suatu Pendekatan Praktik Edisi Refisi VI. Jakarta: Rineka Cipta.

Bariroh, Barorotul. 2010. Metode Reading Guide (Panduan Membaca) Dalam Pembelajaran SKI di Tingkat Madrasah Aliyah (http://elbarir.Blogspot. com/2010/04/metode-readingguide.html. Diakses Rabu, 30 Maret 2013 Pukul 14.50 WIB.

Ernawati, Dewi. 2012. Upaya Meningkatkan Keaktifan Melalui Strategi Reading Guide Di Kolaburasikan Dengan Strategi True Or False Dalam Pembelajaran PKn Pada Siswa Kelas X Program Keahlian Pemasaran I SMK Negeri 1 Banyudono Kabupaten Boyolali Tahun Ajaran 2011/2012.

Haryati, Dyah. 2012. Upaya Meningkatkan Ketuntasan Belajar Materi Makna Proklamasi Kemerdekaan dan Konstitusi Pertama Melalui Strategi Small Group Discussion Di Kolaburasikan Dengan Team Quiz Dalam Pembelajaran Pendidikan Kewarganegaraan Pada Siswa Kelas VII D SMP Negeri 2 Jatipuro Karanganyar Tahun Pelajaran 2011/2012. Surakarta: Skripsi Universitas Muhammadiyah Surakarta.

Http://mashafid78.Blong-spot.com/20110201 arcive.html. Diakses Rabu, 30 April 2013 Pukul 14.20 WIB.

Miles, B. Mathew dan Michael Huberman. 1992. Analisis Data Kualitatif (Buku Sumber tentang Metode-metode Baru). Jakarta: UIP.

Miatun, Aris. 2011. Penerapan Strategi Pembelajaran Card Sort Bervariasi Sebagai Upaya Meningkatkan Keaktifan Siswa Dalam Proses Pembelajaran PKn Materi Budaya Politik Di Indonesia Pada Siswa XI TKR 2 SMK Muhammadiyah 1 Delanggu Klaten Tahun 2010. Surakarta: Skripsi Universitas Muhammadiyah Surakarta.

Zaini, Hisyam dkk. 2008. Strategi Pembelajaran Aktif. Yogyakarta: PT Pustaka Insan Madani. 